\title{
Application of Pavement Condition Index (PCI) on The Assessment of The Kalumata - Fitu Highway Section of Southern of Ternate City
}

\author{
Sabaruddin ${ }^{1}$ \\ Civil Engineering Department \\ Universitas Khairun \\ Ternate Selatan, Indonesia \\ ${ }^{1}$ sabaruddin.new@gmail.com
}

\author{
Rabial Awaludin ${ }^{2}$ \\ Civil Engineering Department \\ Universitas Khairun \\ Ternate Selatan, Indonesia \\ 2rabawal@gmail.com
}

\begin{abstract}
In general, roads are built as infrastructure to facilitate mobility and accessibility of socio-economic activities in society. The existence of the highway is very necessary to support the rate growth of the economy, agriculture and other sectors. Considers to the benefits that are very important, therefore, matters related to the development and maintenance of roads are a priority to be researched and developed in planning, implementing and maintaining them. One of the research targets is one km Kalumata - Fitu highway in Southern Ternate City which suffered significant damage, both minor damage, moderate damage and severe damage to some of these roads. The purpose of this study to determine the type and extent of road surface damage, and to provide measurement damaged road repairing, based on the level and type of damage that occurred. The application of the PCI is carried out by visual survey stages at the research location, determines the type and level of damage and measuring the damage dimensions which include length, width and depth, calculating the area of damage, analyzing the damage condition. Based on the results of the analysis, the surface of the Kalumata-Fitu road in Ternate is classified as a severity level with a PCI value of 4.00. an alternative appropriate improvement is reconstruction.
\end{abstract}

index

Keywords -

; severity level;

\section{INTRODUCTION}

Lately in Southern Ternate city, we often see many vehicles passing on the highway. The number of these vehicles make the road become more crowded from day to day. The trigger of road density in addition to the number of vehicles is due to driving knowledge and damaged road conditions. In general, damaged road such as cracking, corrugation, and damage to grooves extending along the road around the vehicle wheel rutting are also in the form of asphalt pavements on the bleeding surface, and there are also holes (pothole). This damage can occur on the road surface using asphalt concrete as the surface layer. Damaged road like this usually caused by a variety of factors, for example, due to heavy vehicle wheel loads (frequent), high groundwater conditions, the consequences of wrong execution time, and also due to planning errors [1].
The history of the development of the highway along with the level of importance of the movement of people, goods from one place to another as well as the findings of its material building and material technology related to the highway (including road pavement).

Road pavement is a pavement layer that is located between layers of subgrade and wheel of the vehicle that serves to provide services to transportation vehicles, where it is expected that during the service period there will be no significant damage. Therefore, it is our duty to know the cause of the damage and how to maintain the road. In order to create a safe and comfortable way and provide significant benefits for the sustainability and survival of the wider community and become one of the factors making it an improvement in people's life in several aspects of life. [2].

Theoretical and empirical studies show that all road users certainly want safe, comfortable, clean road etc. Therefore, the damage that occurs on the road must be addressed and repaired seriously.

The Kalumata-Fitu section road is far from the ideal, the number of holes and waves on the road, or the former excavation project made a lot of damage on the road. For that reason, research on the types of damage, grouping the types of damage that occurred on the pavement on the road is needed, so that it can be known what should be done to overcome the damage problems that occur in the road as a matter of concern for the surrounding environment, especially the road, so such of those damages will not happened in future, and to prevent bad thing such as accident. The method that used in this study is the pavement condition index to provide input to the road organizer about appropriate handling strategies to be implemented on the road.

\section{LITERATURE STUDY}

\section{A. Definition of Road}

Roads are land transportation which includes all parts of road, including complementary buildings and equipment those are dedicated for traffic, which is at ground level, above ground 
level, under ground level and / or water, and above the water surface, except railroad fire, lorry roads and cable roads [3].

According to Law No. 38 of 2004 concerning roads, in accordance with their design, the road is distinguished by special roads and public roads, both of them are the lifeblood of people's lifes in an effort to develop national and state life [4].

\section{B. Pavement Condition Index (PCI)}

Pavement condition index (PCI) is a system for assessing road pavement conditions by type, the level of damage that occurs and can be used as a reference in the maintenance business. The PCI method provides information on pavement conditions only at the time of the survey, but cannot provide a predictive picture in the future. However, by periodically conducting condition surveys, information on pavement conditions can be useful for predicting future performance, as well as being able to be used as a more detailed measurement input [5].

\section{Severity Level}

The severity level used in calculating PCI is low severity level (L), medium severity level (M) and high severity level (H) [5].

\section{Terms in PCI Count}

\section{Density}

Density is the percentage of the total area or length of one type severity to the area or total length of the part of the road measured. The equation for calculating density values is: Density $=$ Distress amount in $\mathrm{m}^{2} /$ sample unit area in $\mathrm{m}^{2} \mathrm{x} 100$

\section{Deduct Value (DV)}

The deduct values are determined from the deduct value curves for each distress type and severity

\section{Total Deduct Value (TDV)}

A total deduct value (TDV) is computed by summing all individual deduct values.

\section{Corrected Deduct Value (CDV)}

The corrected deduct value (CDV) can be determined from the correction curves. When determining the CDV, if any individual deduct value is higher than the CDV, the CDV is an equal set to the highest individual deduct value. Figure 1 shows corrected deduct values for flexible pavements.

\section{Value PCI}

After the deduction value is corrected, the Pavement Condition Index value for each sample unit is calculated using Equations 2 and 3 as follows:

Where:

$$
\mathrm{PCI}(\mathrm{s})=100-\mathrm{CDV}
$$

$\mathrm{PCI}(\mathrm{s})=$ Pavement Condition Index of pavement section; $\mathrm{CDV}=$ Corrected Deduct Value of pavement section.

For PCI values as a whole on certain road segments shown by the following equation:

$$
\mathrm{PCI}=\Sigma \mathrm{PCI}(\mathrm{s}) / \mathrm{N}
$$

Where:

PCI = overall pavement PCI value.

$\mathrm{PCI}(\mathrm{s})=$ Pavement Condition Index of pavement section $\mathrm{N}=$ Number of units

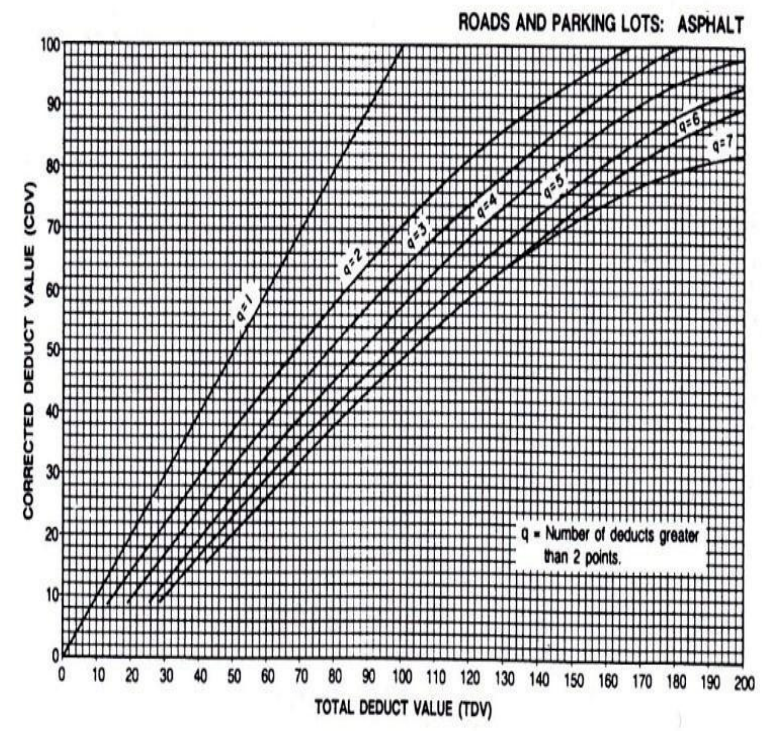

Fig. 1. Corrected deduct values for flexible pavements

Obtained PCI values are used to assess pavement conditions. the value of the pavement conditions suggested by [6] is shown in the table below.

TABLE I. VALUE PCI AND RATING [6]

\begin{tabular}{|r|c|c|}
\hline PCI value & Rating & Treatments \\
\hline $0-10$ & $($ failed $)$ & Reconstruction \\
$11-25$ & (very poor) & Reconstruction \\
$26-40$ & $($ poor $)$ & Periodic \\
$41-55$ & $($ fair $)$ & Routine \\
$56-70$ & $($ good $)$ & Routine \\
$71-85$ & (very good $)$ & Routine \\
$86-100$ & $($ excellent $)$ & Routine \\
\hline
\end{tabular}

\section{E. Flexible Pavement Distresses}

The district road maintenance guide series on flexible pavement maintenance techniques explains the types of flexible pavement distresses, generally can be classified as follows [7]:

1. Deformation / distortion: rutting, corrugation shoving, depression and upheaval

2. Cracking: longitudinal, transverse, diagonal, reflective, block, alligator crack, crescent / slippage cracks.

3. Surface defect: raveling, bleeding, polishing, peeling and stripping

4. Potholes, patches, crossing of railroad tracks.

5. Edge defect: edge break and edge drop. 


\section{METHODOLOGY}

\section{A. Description study area}

The research area was carried out on the Kalumata - Fitu City section of South Ternate.

\section{B. Data Processing}

Data processing can be done anywhere to identify the type of damage and its range based on the level of damage obtained from the road condition survey. Likewise, the stage is always the same everywhere. The steps for conducting condition surveys and determining PCI ratings are carried out according to the literature [8]:

1. Inspect sample unit, determines distress type and severity level and then measure the density;

2. The deduct values are determined from the deduct value curves for each distress type and severity;

3. A total deduct value (TDV) is computed by summing all individual deduct values;

4. Once the TDV is computed, the corrected deduct value (CDV) can be determined from the correction curves. When determining the CDV, if any individual deduct value is higher than the CDV, the CDV is set equal to the highest individual deduct value;

5. The PCI is computed using the relation $\mathrm{PCI}=100-\mathrm{CDV}$.

\section{RESUlT AND DiscusSIONS}

The results and discussion describe the results of the research. The results and discussion are divided into:

A. Identification of Damage Types

The type of damage that occurs on the Kalumata - Fitu road segment is dominated by crack type damage. The following is explained by the extent and percentage of damage according to the level and type of damage that occurs.

Edge 1 crack damage was $0,1668 \%$ of the total damage that occurred with an area of $834 ; 063 \mathrm{~m}^{2}$, the subsequent damage to the edge 2 crack damage was $0.133 \%$ of the total damage that occurred with an area of $665.68 \mathrm{~m}^{2}$. Next the hole damage was $0,5539 \%$ of the total damage, which is $2769,48 \mathrm{~m}^{2}$. Furthermore, crocodile skin crack damage was $0,2009 \%$ of the total damage, with an area of $1004,80 \mathrm{~m} 2$. Next the crack damage expands by $0.19 \%$ from the total damage, which is $973.40 \mathrm{~m}^{2}$. Finally, the damage to the medium hole is $0.57 \%$ of the total damage, which is with an area of $2826 \mathrm{~m}^{2}$.

\section{A. Density}

The density value is obtained by dividing the total area of damage for each level of damage with the area of the sample unit

The value of edge 1 crack density is $2.65 \%$, edge 2 crack is $0.18 \%$, medium hole is $70.29 \%$, crocodile skin crack is $23.73 \%$, crack is $0.21 \%$, medium hole is $0.56 \%$.

\section{B. Deduct Value}

The deduction value is obtained by adjusting the density value obtained into each damage graph according to the level of damage.
Type 1 edge crack damage density $0,265 \%$ with damage level $\mathrm{L}$ is 2 , cracking edge 2 density $0.18 \%$ with damage level $\mathrm{M}$ is 2 . For medium hole density $0,703 \%$ with damage level $\mathrm{M}$ is 80 . For cracked skin density crocodile $0,237 \%$ with damage level $\mathrm{M}$ is 10 . For cracks expand density $0.21 \%$ with damage all level is 0 . Hole is density $0.56 \%$ with damage level $\mathrm{M}$ is 76 .

\section{Total Deduct Value}

The total reduction value is the sum of all deduction values that have been obtained, which in this study is 170 .

\section{Corrected Deduct Value}

With the number $\mathrm{q}=3$ and then plotted into the graph the corrected deduction value is obtained value 96 .

\section{E. Value Pavement Condition Index}

Recapitulation of PCI values on the Kalumata - Fitu road segment is $(100-96,00) / 1$ ie 4,00

\section{F. Type of Handling}

Based on the PCI value obtained, it can be stated that the assessment of failed pavement requires reconstruction

\section{CONCLUSION}

\section{A. Conclusion}

The distresses that occurs on the Kalumata-Fitu road segment is the edge cracking, medium hole, crocodile skin crack, inflated crack. Evaluation on the Kalumata-Fitu road segment results in a PCI value of 4.00 with failed conditions. The type of handling needed on the Kalumata-Fitu road is reconstruction.

\section{B. Recomendation}

1. It is necessary to handle road damage immediately, to provide a sense of security and comfort for road users, given the road conditions that are not in good condition.

2. To facilitate of the maintenance of this road, the authorized agency needs to make great documentation the history of road maintenance and the implementation of the survey in the form of a database system, so that units that are often damaged can get special attention.

\section{REFERENCE}

[1] Bachnas, Pengamat Transportasi, Yogyakarta: Teknik Sipil UII Yogyakarta, 2009.

[2] Permen, "Peraturan Pemerintah Nomor 34 Tahun 2006", Jakarta: Permen, 2006.

[3] JICA bersama Pusat litbang prasarana transportasi Bandung 2005.

[4] H. C. Hardiyatmo, Pemeliharaan Jalan Raya, Yogyakarta : Gajah Mada University Press, 2007.

[5] M. Y. Shahin, Pavement Management for Airport, Road, and Parking Lots, Chapman \& Hall: New York, 1994.

[6] ASTM D6433-09, "American Society for Testing and Materials, "Standard Practice for Roads and Parking Lots Pavement Condition Index Surveys", United States, 2009. 
[7] R. Yuswardi, et al, "Evaluasi Kondisi Perkerasan Jalan Dengan Menggunakan Metode Pavement Condition Index (PCI), (Studi Kasus Ruas Jalan Beureunuen - Batas Keumala)", Jurnal Teknik Sipil Universitas Syiah Kuala, Universitas Syiah Kuala ISSN 2088-9321, ISSN e-2502-5295, pp. $761-768,2018$.

[8] M. A. Karim, et al, "The Road Pavement Condition Index (PCI) Evaluation and Maintenance: A Case Study of Yemen", A Case Study of
Yemen. Organization, Technology and Management In Construction vol. 8, pp. 1446-1455, 2016.

[9] Sabaruddin, et al., "Manufacture of Specimens for Experiment the Main Through Testing Pre Conditions," IJAEMS, vol-2, is sue-8, ISSN:24541311, pp.1399-1401, 2016. 